\title{
Diversitas dan sebaran kumbang staphylinid di lahan pertanaman padi (Oryza sativa L.) dan ubi jalar (Ipomoea batatas L.)
}

\author{
The diversity and distribution of staphylinid beetles \\ in paddy and sweet potato fields
}

\section{Tri Atmowidi*, Taruni Sri Prawasti, Dimas Adjie Prasetyo, Annisa Sendekia Lubis, Nofialdi, Sefriatin Nurmaulani}

Departemen Biologi, Fakultas Matematika dan Ilmu Pengetahuan Alam, Institut Pertanian Bogor Jalan Agatis, Kampus IPB Dramaga, Bogor 16680

(diterima Agustus 2015, disetujui Desember 2015)

\begin{abstract}
ABSTRAK
Kumbang staphylinid (Coleoptera: Staphylinidae) dicirikan dengan elitra yang tidak menutupi seluruh abdomen dan tubuh berwarna oranye, cokelat, dan hitam. Penelitian ini bertujuan menganalisis keanekaragaman dan pola distribusi populasi spesies staphylinid di lahan pertanaman padi dan ubi jalar. Pengamatan keanekaragaman kumbang dilakukan dengan metode road sampling di lahan pertanaman padi dan ubi jalar. Pengamatan distribusi populasi kumbang dilakukan dalam plot berukuran $1 \mathrm{~m} \mathrm{x}$ $1 \mathrm{~m}$ yang diletakkan secara sistematik di lahan pertanaman ubi jalar. Penelitian ini mendapatkan 7 spesies kumbang staphylinid, lima spesies kumbang (Paederus fuscipes Curtis, Stenus sp., Astenus sp., Hypostenus sp., dan Cryptobium abdominale Motsch.) didapatkan dari lahan pertanaman padi dan 5 spesies (P. fuscipes, Medon sp., Stenus sp., Hypostenus prahoeensis Benick, dan Philonthus sp.) didapatkan di lahan pertanaman ubi jalar. Kumbang $P$. fuscipes ditemukan dominan di kedua tipe lahan. Indeks keanekaragam spesies kumbang staphylinid di lahan pertanian termasuk rendah. Di habitat ubi jalar, kumbang $P$. fuscipes memiliki indeks nilai penting tertinggi ( $\mathrm{INP}=115,98 \%$ ), diikuti Stenus sp. (69,35\%), dan H. prahoeensis (5,65\%). Kumbang P. fuscipes, Medon sp., Stenus sp., dan Philonthus sp. mempunyai pola sebaran seragam, sedangkan $H$. prahoeensis mempunyai pola sebaran mengelompok.
\end{abstract}

Kata kunci: distribusi populasi, keanekaaragaman, lahan pertanian, staphylinid

\begin{abstract}
Staphylinid beetle (Coleoptera) is characterized by short elytra with orange, brown, or black body color. The objective of this research was to analyse diversity of staphylinid beetles in paddy and sweet potato fields and distribution of the species in sweet potato field. Collections of beetle were done by using road sampling method in two types of agricultural fields. Distribution of beetle population were observed in the plots $(1 \mathrm{~m} \times 1 \mathrm{~m})$ placed systematically. Seven species of staphylinids were found in this research. Five species (Paederus fuscipes Curtis, Stenus sp., Astenus sp., Hypostenus sp., and Cryptobium abdominale Motsch.) were found in paddy fields. We also found five species of staphylinid beetles $(P$. fuscipes, Medon sp., Stenus sp., Hypostenus prahoeensis Benick, and Philonthus sp.) in sweet potato fileds. In paddy and sweet potato fileds were dominated by $P$. fuscipes. Diversity of staphylinid in paddy and sweet potato fields were low. In sweet potato fields, $P$. fuscipes showed highest important value index (115.98\%), followed by Stenus sp. (69.35\%), and H. prahoeensis (5.65\%). and Population distribution of P. fuscipes, Medon sp., Stenus sp., dan Philonthus sp. were uniform, while H. prahoeensis was clump.
\end{abstract}

Key words: agricultural fields, diversity, population distribution, staphylinid

\footnotetext{
*Penulis korespondensi: Tri Atmowidi. Departemen Biologi, Fakultas Matematika dan Ilmu Pengetahuan Alam, Institut Pertanian Bogor, Jalan Agatis, Kampus IPB Dramaga, Bogor 16680 


\section{PENDAHULUAN}

Kumbang staphylinid(Coleoptera: Staphylinidae) merupakan famili kedua terbesar dari Ordo Coleoptera dengan lebih dari 47.000 spesies telah diketahui yang termasuk dalam 3.300 genus (Newton et al. 2000). Sekitar 3.000 spesies kumbang staphylinid dilaporkan di India (Basak \& Pal 2006). Kumbang staphylinid memiliki bentuk tubuh memanjang, ukuran kecil $(<1 \mathrm{~cm})$, dan elitra pendek dan ditemukan di hampir semua tipe habitat di darat. Kumbang ini dapat ditemukan di serasah lantai hutan, rerumputan, buah dan kayu membusuk, kotoran hewan, dan beberapa spesies berasoasiasi dengan bunga (Frank \& Thomas 2011). Ekosistem hutan berperan penting dalam memelihara keanekaragaman kumbang staphylinid (Apigian et al. 2006).

Genus Paederus merupakan anggota staphylinid yang tersebar di benua Amerika, Sri Langka, Birma, Malaysia, Filipina, India, dan Indonesia (Cameron 1931). Sekitar 600 spesies dari genus Paederus telah dideskripsikan (Kanamitsu \& Frank 1987). Kumbang P. fuscipes merupakan predator penting bagi hama tanaman kedelai, seperti Helicoverva armigera Hübner (Winasa et al. 2007). Kumbang ini juga berperan sebagai predator penting pada pertanaman padi (Kartohardjono 1992), namun kumbang ini sensitif terhadap pestisida (Kanamitsu \& Frank 1987).

Tujuan dari penelitian ini adalah menganalisis keanekaragaman, dominansi, dan pola sebaran populasi kumbang staphylinid di lahan pertanaman padi dan pertanaman ubi jalar di daerah Bogor dan sekitarnya.

\section{BAHAN DAN METODE}

Pengamatan dan koleksi kumbang staphylinid

Pengamatan kumbang dilakukan pada pertanaman padi basah yang merupakan lingkungan akuatik dan pertanaman ubi jalar yang merupakan lingkungan terestrial. Kedua pertanaman tersebut dipilih karena ditemukan di semua lokasi yang digunakan dalam penelitian ini. Pengamatan dan koleksi kumbang staphylinid dilakukan di sembilan lokasi pertanaman padi pada bulan Januari-Maret 2013 di desa Leuwikopo, Sindangbarang, dan Situgede. Pengamatan kumbang staphylinid 82 juga dilakukan pada bulan November 2013Februari 2014 di Bojongrangkas, Cibeureum, Sindangbarang, Cibinong, Cipaku, Cikarawang dan bulan September 2014 di Cipeutey, Sukabumi. Pengamatan dilakukan pada pertanaman padi basah yang telah membentuk bulir dengan luas sekitar $12 \mathrm{~m}$ x $20 \mathrm{~m}$. Pengamatan kumbang staphylinid juga dilakukan pada pertanaman ubi jalar pada bulan Januari-Maret 2013 di desa Leuwikopo, Sindangbarang, dan Situgede dan bulan November 2013-Februari 2014 di desa Bojongrangkas, Cibeureum, Cibinong, Cimanggu, Cipaku, Dramaga, Sindangbarang, dan bulan Oktober 2014 di Nirmala, Sukabumi (Tabel 1, Gambar 1). Di setiap lokasi, pengamatan kumbang dilakukan selama 3 hari pada pukul 06:00-09:00, kecuali di Cipeutey dan Nirmala yang dilakukan dalam satu hari pada pukul 13:00-16:00. Pengamatan kumbang dilakukan dengan metode road sampling (Ratti \& Garton 1996), yaitu mengamati kumbang dengan berjalan di pematang sawah mengelilingi pertanaman padi. Pada pertanaman ubi jalar pengamatan dengan metode road sampling dilakukan dengan mengamati kumbang dengan berjalan diantara pertanaman ubi jalar dengan luas sekitar $10 \mathrm{~m} \mathrm{x}$ $10 \mathrm{~m}$. Kumbang yang ditemukan dicatat, dihitung jumlah individunya, dan dilakukan koleksi untuk diidentifikasi. Berdasarkan informasi dari pemilik lahan, pada pertanaman padi dilakukan penyemprotan pestisida kimia satu kali yang dilakukan sebelum pertanaman membentuk bulir, sedangkan pertanaman ubi jalar tidak dilakukan penyemprotan pestisida. Unsur cuaca pada pertanaman padi yang digunakan sebagai lokasi pengambilan sampel kumbang adalah suhu berkisar $24-32{ }^{\circ} \mathrm{C}$, kelembapan udara $58-83 \%$, dan intensitas cahaya 5.250-14.670 lux. Pada pertanaman ubi jalar, unsur cuaca adalah suhu udara berkisar $24-31{ }^{\circ} \mathrm{C}$, kelembapan udara $41-$ $81 \%$, dan intensitas cahaya 1.000-15.130 lux.

\section{Pengukuran indeks nilai penting dan pola sebaran populasi}

Pengukuran indeks nilai penting dan pola sebaran populasi kumbang staphylinid hanya dilakukan di lahan pertanaman ubi jalar. Di lahan pertanaman padi tidak dibuat plot sehingga tidak dilakukan penghitungan indeks nilai penting dan pola sebaran populasi kumbang staphylinid. 
Tabel 1. Metode yang digunakan dalam pengamatan keanekaragaman dan pola sebaran kumbang staphylinid di masing-masing lokasi

\begin{tabular}{llll}
\hline Pertanaman & \multicolumn{1}{c}{ Lokasi pengamatan } & Metode & \multicolumn{1}{c}{ Pengukuran } \\
\hline Padi & $\begin{array}{l}\text { Leuwikopo, Situgede, Cikarawang, Cibeureum, } \\
\text { Sindangbarang, Sindangbarangjero, Bojongrangkas, } \\
\text { Cibinong, Cipaku, Cipeutey-Sukabumi }\end{array}$ & Road sampling & $\begin{array}{l}\text { Keanekaragaman } \\
\text { kumbang staphylinid }\end{array}$ \\
Ubi jalar & $\begin{array}{l}\text { Leuwikopo, Situgede, Cikarawang, Cibeureum, } \\
\text { Sindangbarang, Dramaga, Bojongrangkas, Cibinong, } \\
\text { Cipaku, Cimanggu, Nirmala-Sukabumi }\end{array}$ & Road sampling & $\begin{array}{l}\text { Keanekaragaman } \\
\text { kumbang staphylinid }\end{array}$ \\
Ubi jalar & $\begin{array}{l}\text { Cibeureum, Cipaku, Cibinong, Bojongrangkas, } \\
\text { Cimanggu, Sindangbarang, Dramaga }\end{array}$ & Plot (1 m x 1 m) & $\begin{array}{l}\text { Pola sebaran kumbang } \\
\text { staphylinid }\end{array}$ \\
\hline
\end{tabular}

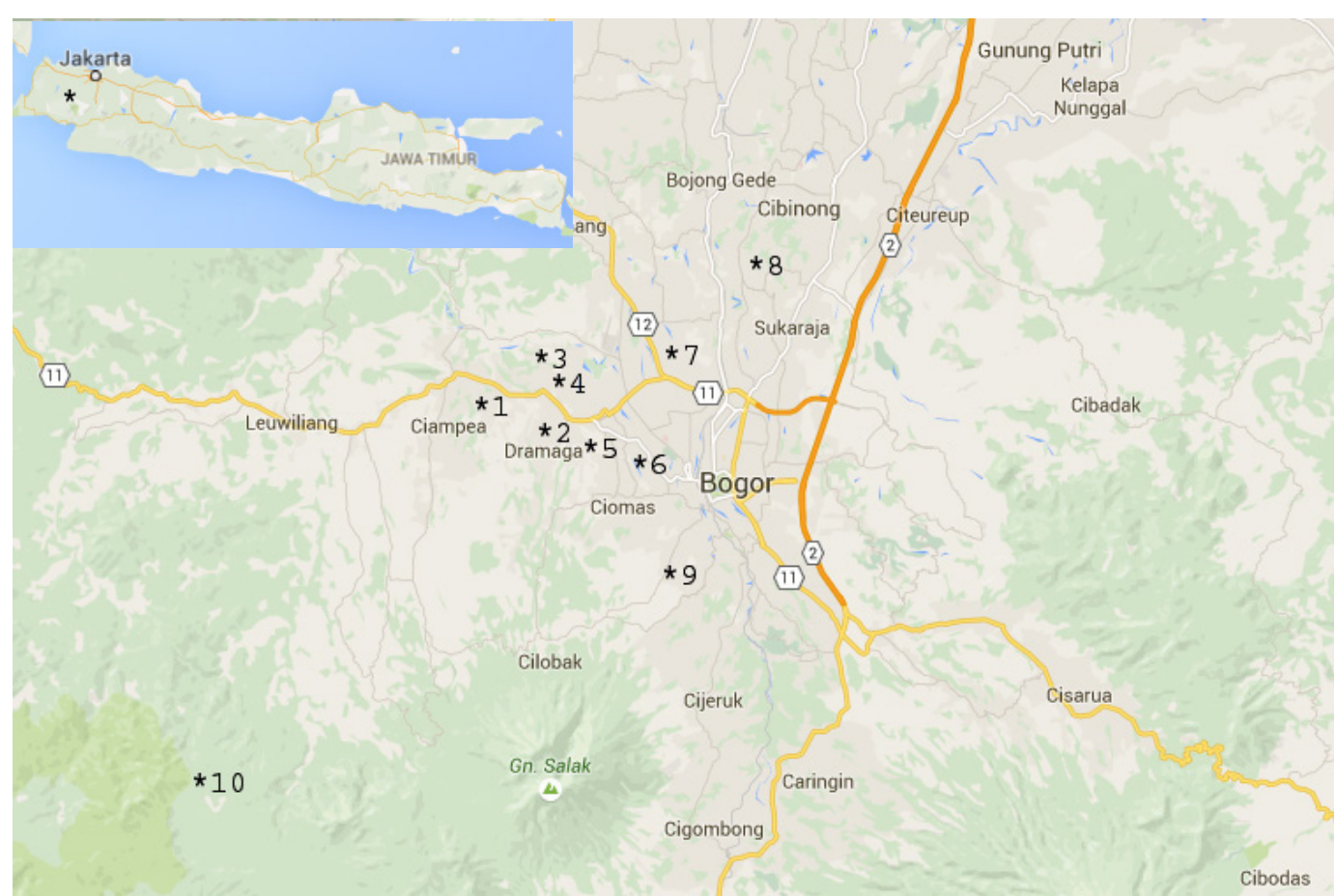

Gambar 1. Lokasi pengambilan dan pengamatan kumbang staphylinid. 1: Bojongrangkas (Ciampea); 2: Leuwikopo (Dramaga); 3: Cikarawang; 4: Situgede; 5: Cibeureum; 6: Sindangbarang; 7: Cimanggu; 8: Cibinong; 9: Cipaku; dan 10: Cipeutey.

Sebanyak 10 plot, masing-masing berukuran $1 \mathrm{~m}$ x $1 \mathrm{~m}$, dibuat pada pertanaman ubi jalar di desa Cibereum, Cipaku, Cibinong, Bojongrangkas, Cimanggu, Sindangbarang, dan Dramaga. Plot tersebut diletakkan secara sistematis dengan jarak antar plot sekitar $0,3 \mathrm{~m}$. Pengamatan populasi kumbang pada masing-masing lokasi dilakukan tiga kali.

\section{Identifikasi kumbang staphylinid}

Spesimen staphylinid yang didapatkan diawetkan dalam ethanol $70 \%$ dan diidentifikasi berdasarkan Cameron (1930; 1931; 1932). Spesimen kumbang diverifikasi di Museum
Entomologi, Bidang Zoologi (Museum Zoologicum Bogoriense), Pusat Penelitian Biologi - LIPI, Cibinong dan dideposit di Laboratorium Biosistematika dan Ekologi Hewan, Departemen Biologi, Fakultas Matemaika dan Ilmu Pengetahuan Alam, Institut Pertanian Bogor.

\section{Analisis data}

Keanekaragaaman kumbang staphylinid dianalisis dengan indeks Shannon-Wiener (H') dan indeks kemerataan (evenness) Pielou (J') (Magurran 1987). Indeks nilai penting (INP) dihitung berdasarkan jumlah dari kerapatan relatif (KR) dan frekuensi relatif (FR). Pola sebaran 
spesies kumbang ditentukan dengan menghitung indeks dispersi Morisita $\left(I_{\mathrm{d}}\right)$. Karena hasil indeks dispersi Morisita sulit untuk diinterpretasikan sehingga dilakukan penghitungan indeks Morisita yang distandarkan (Krebs 1999), yang terlebih dahulu dilakukan penghitungan indeks seragam (uniform index) $\left(\mathrm{M}_{\mathrm{u}}\right)$ dan indeks mengelompok (clump index) $\left(\mathrm{M}_{\mathrm{c}}\right)$. Nilai indeks dispersi Morisita yang distandarkan (Ip) berkisar dari -1 sampai +1 dengan tingkat kepercayaan 95\%. Penyebaran populasi ditunjukkan dari nilai Ip $<1$ (seragam), Ip $=1$ (acak), dan Ip $>1$ (mengelompok).

\section{HASIL}

\section{Keanekaragamaan kumbang staphylinid}

Pada penelitian ini dikoleksi 672 individu staphylinid (409 individu dari pertanaman padi dan 263 individu dari pertanaman ubi jalar) yang termasuk dalam tujuh spesies, yaitu Paederus fuscipes Curtis, Stenus sp., Astenus sp., Hypostenus sp., Cryptobium sp., Medon sp., dan Philonthus sp. Pada pertanaman padi ditemukan 5 spesies staphylinid, yaitu P. fuscipes, Stenus sp., Astenus sp., Hypostenus sp., dan Cryptobium abdominale Motsch. Kumbang P. fuscipes ditemukan dominan (391 individu, 95\%). Kumbang ini ditemukan di 10 lahan pertanaman padi yang diamati. Kumbang C. abdominale ditemukan cukup tinggi (9 individu di Situgede, dan 1 individu di Sindangbarang. Kumbang Stenus sp., Astenus sp., dan Hypostenus sp. ditemukan dengan jumlah individu yang rendah (kurang dari 5 individu) (Tabel 2).

Di lahan pertanaman ubi jalar dikoleksi 5 spesies staphylinid, yaitu $P$. fuscipes, Medon sp., Stenus sp., Hypostenus prahoeensis, dan Philonthus sp. Seperti pada pertanaman padi, di lahan ubi jalar juga didominasi oleh kumbang P. fuscipes (175 individu). Empat lokasi yang ditemukan $P$. fuscipes dengan kelimpahan tinggi, yaitu Leuwikopo (40 individu), Situgede (57 individu), Cikarawang (41 individu), dan Cipeutey (33 individu). Kumbang Stenus sp. juga ditemukan dengan kelimpahan tinggi (76 individu) yang ditemukan di 12 lokasi dan 2 lokasi ditemukan cukup melimpah, yaitu Cibinong (18 individu) dan Cimanggu (12 individu). Kumbang yang ditemukan dengan kelimpahan rendah, yaitu Medon sp. (3 individu) dikoleksi dari Cikarawang dan kumbang $H$. prahoeensis (6 individu) dan Philonthus sp. (3 individu) ditemukan di Cipaku (Tabel 3). Secara umum, indeks keanekaragaman spesies staphylinid di lahan ubi jalar $\left(\mathrm{H}^{\prime}=0,82\right.$, $\left.\mathrm{J}^{\prime}=0,51\right)$ lebih tinggi dibandingkan dengan pertanaman padi $\left(\mathrm{H}^{\prime}=0,23, \mathrm{~J}^{\prime}=0,14\right)$. Indeks keanekaragaman yang rendah di lahan pertanaman padi disebabkan oleh terdapat dominansi kumbang $P$. fuscipes yang sangat tinggi (90\%).

\section{Indeks nilai penting dan pola sebaran staphylinid}

Di habitat ubi jalar, kumbang $P$. fuscipes memiliki indeks nilai penting (INP) paling tinggi (INP $=115,98 \%)$, diikuti Stenus sp. $(69,35 \%)$,

Tabel 2. Jumlah individu kumbang staphylinid di habitat pertanaman padi di Bogor dan sekitarnya

\begin{tabular}{|c|c|c|c|c|c|c|c|c|c|c|c|}
\hline \multirow{2}{*}{ Spesies } & \multicolumn{3}{|c|}{ Januari-Maret 2013} & \multicolumn{6}{|c|}{ November 2013-Februari 2014} & \multirow{2}{*}{$\begin{array}{c}\text { September } \\
2014 \\
\mathrm{CiP}\end{array}$} & \multirow{2}{*}{$\begin{array}{c}\text { Jumlah } \\
\text { total } \\
\text { individu }\end{array}$} \\
\hline & LK & SD & SG & BR & $\mathrm{CB}$ & SD & $\mathrm{CBi}$ & $\mathrm{CP}$ & $\mathrm{CK}$ & & \\
\hline Paederus fuscipes & 43 & 36 & 31 & 31 & 11 & 35 & 123 & 31 & 34 & 16 & 391 \\
\hline Stenus sp. & & 1 & & & & & & 2 & & & 3 \\
\hline Cryptobium abdominale & & 1 & 9 & & & & & & & & 10 \\
\hline Astenus sp. & & & & & & & 1 & & & & 1 \\
\hline Hypostenus sp. & & & & & & & 4 & & & & 4 \\
\hline Jumlah individu & 43 & 38 & 40 & 31 & 11 & 35 & 128 & 33 & 34 & 16 & 409 \\
\hline Jumlah spesies & 1 & 3 & 2 & 1 & 1 & 1 & 3 & 2 & 1 & 1 & 5 \\
\hline Indeks Shannon (H') & & & & & & & & & & & 0,23 \\
\hline Kemerataan Pielou (J') & & & & & & & & & & & 0,14 \\
\hline
\end{tabular}

LK: Leuwikopo; SG: Situgede; CK: Cikarawang; BR: Bojongrangkas; CB: Cibeurem; CBi: Cibinong; CP: Cipaku; SD: Sindangbarang; CiP: Cipeutey, Sukabumi. 
dan H. prahoeensis (5,65\%). Di habitat ubi jalar, kumbang P. fuscipes, Medon sp., Stenus sp., dan Philonthus sp. mempunyai pola sebaran seragam (Ip $<1$ ), sedangkan $H$. prahoeensis mempunyai pola sebaran mengelompok (Tabel 4).

\section{PEMBAHASAN}

Kumbang $P$. fuscipes dominan ditemukan pada pertanaman padi dan ubi jalar. Kumbang ini ditemukan pada batang, daun, dan tajuk tanaman padi. Kumbang ini juga ditemukan di permukaan tanah, pematang sawah, dan tersembunyi di bawah tanaman liar sekitar pematang sawah. Hendrival et al. (2011) melaporkan imago P. fuscipes banyak ditemukan di tajuk tanaman, sedangkan larvanya hidup dan mencari mangsa di permukaan tanah.
Kelimpahan populasi kumbang ini dapat dipengaruhi oleh fenologi tanaman dan ketersediaan mangsa berupa wereng batang coklat (Winasa et al. 2007). Kumbang P. fuscipes merupakan predator yang bersifat polifag (Kalshoven 1981) yang berperan dalam pengendalian hayati populasi hama wereng di persawahan dan perkebunan (Widya 2005). Kumbang ini memangsa hama utama tanaman padi, yaitu nimfa dan imago Nilaparvata lugens (Stål), Sogatella furcifera (Horváth), Laodelphax striatellus Fallen, Nephotettix cincticeps Matsumura, Tryporyza incertulas (Walker), larva Cnaphalocrocis medinalis (Guenee), dan Naranga aenescens Moore (Lou et al. 2013). Kumbang $P$. fuscipes juga dilaporkan memangsa larva Spodoptera litura (Fabricius) (Aprilizah 2006), telur dan larva $H$. armigera (Winasa et al. 2007), dan Bemisia tabaci (Gennadius) (Sudarjat

Tabel 3. Jumlah individu kumbang staphylinid di habitat pertanaman ubi jalar di Bogor dan sekitarnya

\begin{tabular}{|c|c|c|c|c|c|c|c|c|c|c|c|c|c|c|}
\hline \multirow[t]{2}{*}{ Spesies } & \multicolumn{3}{|c|}{$\begin{array}{l}\text { November 2012- } \\
\text { Februari } 2013\end{array}$} & \multicolumn{9}{|c|}{ November 2013-Februari 2014} & \multirow{2}{*}{$\begin{array}{c}\text { Oktober } \\
2014 \\
\text { NM }\end{array}$} & \multirow{2}{*}{$\begin{array}{c}\text { Jumlah } \\
\text { total } \\
\text { individu }\end{array}$} \\
\hline & LK & SG & $\mathrm{CK}$ & $\mathrm{BR}$ & CB-1 & $\mathrm{CB}-2$ & $\mathrm{CBi}$ & $\mathrm{CM}$ & $\mathrm{CP}-1$ & $\mathrm{CP}-2$ & DR & $\mathrm{SD}$ & & \\
\hline Paederus fuscipes & 40 & 57 & 41 & & & 3 & & & & 1 & & & 33 & 175 \\
\hline Medon sp. & & & 3 & & & & & & & & & & & 3 \\
\hline Stenus sp. & & 3 & 1 & 3 & 6 & 7 & 18 & 12 & 6 & 3 & 4 & 6 & 7 & 76 \\
\hline $\begin{array}{l}\text { Hypostenus } \\
\text { prahoeensis }\end{array}$ & & & & & & & & & 6 & & & & & 6 \\
\hline Philonthus sp. & & & & & & & & & & 3 & & & & 3 \\
\hline Jumlah individu & 40 & 60 & 45 & 3 & 6 & 10 & 18 & 12 & 12 & 7 & 4 & 6 & 40 & 263 \\
\hline Jumlah spesies & 1 & 2 & 3 & 1 & 1 & 2 & 1 & 1 & 2 & 3 & 1 & 1 & 2 & 5 \\
\hline Indeks Shannon (H') & & & & & & & & & & & & & & 0,82 \\
\hline Kemerataan Pielou (J') & & & & & & & & & & & & & & 0,51 \\
\hline
\end{tabular}

LK: Leuwikopo; SG: Situgede; CK: Cikarawang; BR: Bojongrangkas; CB: Cibeurem; CBi: Cibinong; CM: Cimanggu; CP: Cipaku; DR: Dramaga; SD: Sindangbarang; NM: Nirmala, Sukabumi.

Tabel 4. Indeks nilai penting dan pola sebaran staphylinid pada pertanaman ubi jalar

\begin{tabular}{lrrrrrrrrrl}
\hline Spesies & N & K & $\begin{array}{r}\text { KR } \\
(\%)\end{array}$ & Plot & F & $\begin{array}{r}\text { FR } \\
(\%)\end{array}$ & INP (\%) & Id & Ip & Pola sebaran \\
\hline Paederus fuscipes & 175 & 0,67 & 66,54 & 44 & 0,49 & 49,44 & 115,98 & 0,23 & $-0,88$ & Seragam \\
Medon sp. & 3 & 0,01 & 1,14 & 3 & 0,03 & 3,37 & 4,51 & 0,00 & $-0,16$ & Seragam \\
Stenus sp. & 76 & 0,29 & 28,90 & 36 & 0,40 & 40,45 & 69,35 & 0,20 & $-0,89$ & Seragam \\
Hypostenus prahoeensis & 6 & 0,02 & 2,28 & 3 & 0,03 & 3,37 & 5,65 & 2,67 & 0,42 & Mengelompok \\
Philonthus sp. & 3 & 0,01 & 1,14 & 3 & 0,03 & 3,37 & 4,51 & 0,00 & $-0,159$ & Seragam \\
\hline Total & 263 & 1,00 & 100 & 89 & 1 & 100 & 200 & & & \\
\hline
\end{tabular}

$\mathrm{N}$ : jumlah individu masing-masing spesies; K: kerapatan; KR: kerapatan relatif; F: frekuensi; FR: frekuensi relatif; INP: indeks nilai penting; Id: indeks dipersi Morisita; Ip: indeks Morisita yang distandarkan. 
et al. 2009). Aplikasi pestisida untuk pengendalian hama dapat berdampak menurunnya populasi kumbang staphylinid (Herlinda et al. 2008).

Secara alami, $P$. fuscipes mempunyai senyawa paederin yang bersifat toksik yang dihasilkan oleh bakteri simbion di dalam hemolimfe. Senyawa ini dapat menimbulkan dermatitis pada manusia (Frank \& Thomas 2011). Paederus dermatitis (PD) merupakan iritasi akut pada kulit akibat kontak dengan paederin. Kasus PD telah dilaporkan di beberapa negara, seperti Irak (Davidson et al. 2009) dan Korea Selatan (Kim et al. 2007). Spesies kumbang lain yang ditemukan di lahan pertanaman padi adalah C. abdominale. Kumbang ini tidak ditemukan pada pertanaman ubi jalar. Panjang tubuh kumbang ini sekitar $6 \mathrm{~mm}$, berwarna hitam, bagian toraks dan abdomen berwarna cokelat kehitaman, sebagian elitra dan segmen ke lima abdomen berwarna merah, 11 ruas antena berwarna kuning-coklat (Cameron 1931). Genus ini juga dilaporkan di India (Cameron 1931).

Di lahan pertanaman ubi jalar, $P$. fuscipes juga ditemukan dominan, diikuti kumbang Stenus sp. Kumbang Stenus sp. ditemukan di bawah daun, batu, serasah daun, di atas tanah, dan batang tanaman. Di lahan pertanaman padi, populasi kumbang ini sangat rendah. Bohac (1999) juga melaporkan kumbang Stenus hidup di daerah yang lembap dengan serasah. Genus ini telah dilaporkan di Jerman, Rusia, Mexico, Costa Rica (Putzh 2006), Indonesia, Burma, Vietnam, dan China (Cai $\&$ Hong 2008).

Kumbang $H$. prahoeensis ditemukan di lahan pertanaman padi dan ubi jalar dengan populasi rendah. Kumbang ini ditemukan pada tangkai dan batang tanaman ubi jalar, batang tanaman padi, dan permukaan tanah. Kumbang ini juga ditemukan pada tanaman liar di sekitar pertanaman padi dan ubi jalar. Cameron (1932) melaporkan Hypostenus ditemukan pada petanaman dekat perairan. Kumbang Hypostenus telah dilaporkan di Amerika Tengah dan Selatan (Puthz 2006). Kumbang $H$. bispinus dilaporkan di Nalanda, Myanmar, IndoChina, dan Sumatra, Indonesia. Kumbang Astenus sp. ditemukan di lahan persawahan di Cibinong. Genus ini juga dilaporkan Herlinda et al. (2004) di ekosistem persawahan di daerah Cianjur, Jawa Barat. Kumbang ini telah dilaporkan di India, Myanmar, dan Indonesia (Jawa dan Sumatra) (Cameron 1931).
Kumbang Philonthus ditemukan di lahan ubi jalar di daerah Cipaku. Cameron(1932) melaporkan kumbang ini dapat ditemukan pada habitat yang mempunyai serasah. Riyanto et al. (2011) melaporkan kumbang Philonthus juga dilaporkan di dataran tinggi sentra sayuran Kerinjing, Sumatra Selatan sebagai predator Aphis gossypii Glover. Berdasarkan morfospesies, Philonthus yang ditemukan kemungkinan terdiri 3 spesies. Kumbang lain yang ditemukan ialah Medon sp. pada lahan pertanaman ubi jalar Cikarawang. Populasi kumbang ini di alam dilaporkan rendah (Abdel-Dayem et al. 2007), namun kumbang ini berperan sebagai bioindikator kesuburan tanah dan predator bagi telur dan larva Diptera (Cameron 1930). Kumbang ini telah dilaporkan di Mesir (Abdel-Dayem et al. 2007), dan Korea, China, Jepang (Kim et al. 2011).

Indeks nilai penting (INP) menunjukkan peranan suatu spesies dalam ekosistem. Nilai indeks nilai penting merupakan penjumlahan dari kerapatan relatif dengan frekuensi relatif. Nilai INP yang tinggi menunjukkan spesies tersebut memiliki peran penting dalam ekosistem (Fachrul 2008). Di habitat ubi jalar, kumbang $P$. fuscipes mempunyai INP tertinggi $(169,59 \%)$ sehingga memiliki peran paling besar dibandingkan dengan spesies lain. Besarnya nilai INP kumbang $P$. fuscipes dapat diketahui dari dominansi spesies kumbang ini di lahan pertanaman ubi jalar (175 individu).

Pola sebaran spesies dapat berubah dengan berubahnya intensitas gangguan (Sapkota et al. 2009), mereflesikan respons spesies terhadap gangguan, yaitu dengan berubahnya kondisi habitat (Sagar et al. 2003), dan adanya kompetisi (Rozas \& Prieto 2000). Di lahan pertanaman ubi jalar, empat spesies kumbang yang diamati, yaitu P. fuscipes, Medon sp., Stenus sp., dan Philonthus sp. menunjukkan pola sebaran seragam, sedangkan kumbang $H$. prahoeensis menyebar mengelompok. Pola sebaran seragam pada kumbang staphylinid terjadi karena kumbang ini termasuk serangga soliter dan diduga sumberdaya tersedia secara merata di habitat ubi jalar. Pola sebaran mengelompok juga dilaporkan Jongjitvimol et al. (2005) pada penyebaran sarang lebah tak bersengat (stingless bee, Trigona collina Smith) di hutan campuran di Thailand. Pola agregasi sarang lebah tak bersengat ini diduga untuk mengurangi serangan hama dan penyakit. 
Hasil penelitian menunjukkan keanekaragam kumbang staphylinid di habitat pertanaman padi dan ubi jalar cukup tinggi. Kumbang ini berperan sebagai predator yang berperan penting dalam mengendalikan populasi hama. Oleh karena itu, perlu dilakukan konservasi terhadap kumbang staphylinid, salah satunya dengan mengurangi aplikasi pestisida pada lahan tersebut. Hal ini karena kumbang staphylinid rentan terhadap pestisida. Pada penelitian ini tidak mengkaji pengaruh pestisida terhadap keanekaragaman kumbang staphylinid sehingga data yang dihasilkan tidak bisa menjelaskan secara langsung pengaruh pestisida terhadap keanekaragaman kumbang staphylinid.

\section{KESIMPULAN}

Dalam penelitian ini ditemukan tujuh spesies kumbang staphylinid di lahan pertanaman padi dan ubi jalar, yaitu $P$. fuscipes, Stenus sp., Astenus sp., Hypostenus sp., Cryptobium sp., Medon sp. dan Philonthus sp. Kumbang P. fuscipes ditemukan paling dominan dan memiliki indeks nilai penting tertinggi. Keanekaragaman kumbang staphylinid di lahan pertanaman padi dan ubi jalar termasuk rendah. Di habitat ubi jalar, kumbang P. fuscipes, Medon sp., Stenus sp., dan Philonthus sp. mempunyai pola sebaran seragam, sedangkan $H$. prahoeensis mempunyai pola sebaran mengelompok. Dengan pola penyebaran mengelompok, keefektifan kumbang H. prahoeensis dalam mengendalikan populasi mangsa kemungkinan rendah.

\section{UCAPAN TERIMA KASIH}

Penulis mengucapkan terima kasih kepada DIKTI yang telah memberikan dana penelitian melaui Penelitian Unggulan Strategis Nasional, DIPA IPB tahun 2013 dan 2014 atas nama Tri Atmowidi.

\section{DAFTAR PUSTAKA}

Abdel-Dayem MS, Orabi GM, Semida FM. 2007. Assesing the potensial role of beetles as bioindicators in South Sinai, Egypt. Proceedings of the $2^{\text {nd }}$ International Conference of the Entomological Society of Egypt 1:147-168.

Apigian, K, Dahlsten DL, Stephens SL. 2006. Fire and fire surrogate treatment effects on leaf litter arthropods in a western Sierra Nevada mixedconifer forest. Forest Ecology and Management 221:110-122. doi: http://dx.doi.org/10.1016/j. foreco.2005.09.009.

Aprilizah T. 2006. Pengaruh Kerapatan Predator terhadap Pemangsaan Larva Spodoptera litura F. (Lepidoptera: Noctuidae). Skripsi. Bogor: Institut Pertanian Bogor.

Basak PK, Pal TK. 2006. Study of beetles (Coleoptera) associated with stored products of Kolkata, India III. Family: Staphylinidae. Journal of Biosciences 14:49-55.

Bohac J. 1999. Staphylinids beetles as bioindicators. griculture, Ecosystems \& Environment 74:357372. doi: http://dx.doi.org/10.1016/s01678809(99)00043-2.

Cai YZ, Hong ZZ. 2008. Taxonomy on the Cicideloides group of the Stenus Latreille (Coleoptera: Staphylinidae: Steninae). Annales de la Société Entomologique de France 44:8791. doi: http://dx.doi.org/10.1080/00379271.200 8.10697546.

Cameron M. 1930. The fauna of british India. Di dalam: Ceylon \& Burma, (Eds.) Coleoptera. Staphylinidae-Vol. I. London: Taylor and Francis Red Lion Court, Fleet Street.

Cameron M. 1931. The fauna of british india. Di dalam: Ceylon \& Burma (Eds.) Coleoptera. Staphylinidae-Vol. II. London: Taylor and Francis Red Lion Court, Fleet Street.

Cameron M. 1932. The fauna of british india. Di dalam: Ceylon \& Burma (Eds.) Coleoptera. Staphylinidae-Vol. III. London: Taylor and Francis Red Lion Court, Fleet Street.

Davidson SA, Norton SA, Carder MC, Debboun, M. 2009. Outbreak of dermatitis linearis caused by Paederus ilsae and Paederus iliensis (Coleoptera: Staphylinidae) at a military base in Iraq. United States Army Medical Department Journal July-Sept: 6-15.

Fachrul MF. 2008. Metode Sampling Bioekologi. Jakarta: Bumi Aksara.

Frank JH, Thomas MC. 2011. Rove beetles of the world, Staphylinidae (Insecta: Coleoptera: Staphylinidae). EENY 14:1-8.

Hendrival, Hidayat P, Nurmansyah A. 2011. Keanekaragaman dan kelimpahan musuh alami Bemisia tabaci (Gennadius) (Hemiptera: 
Aleyrodidae) pada pertanaman cabai merah di Kecamatan Pakem, Kabupaten Sleman, Daerah Istimewa Yogyakarta. Jurnal Entomologi Indonesia 8:96-109.

Herlinda S, Rauf A, Sosromarsono, Kartosuwondo U, Siswandi, Hidayat P. 2004. Arthropoda predator penghuni ekosistem persawahan di daerah Cianjur, Jawa Barat. Jurnal Entomologi Indonesia 1:9-15.

Herlinda S, Waluyo, Estuningsih SP, Irsan C. 2008. Perbandingan keanekaragaman spesies dan kelimpahan arthropoda predator penghuni tanah di sawah lebak yang diaplikasikan dan tanpa aplikasi insektisida. Jurnal Entomologi Indonesia 5:96-107.

JongjitvimolT, BoontawonK, Wattanachaiyingcharroeni W, Deowanish S. 2005. Nest dispersion of a stingless bee species, Trigona collina Smith, 1857 (Apidae, Meliponinae) in a mixed deciduous forest in Thailand. The Natural History Journal of Chulalongkorn University 5:69-71.

Kalshoven LGE. 1981. The Pests of Crops in Indonesia. Laan PA van der, penerjemah. Jakarta: Ichtiar Baru-van Hoeve. Terjemahan dari: De Plagen van de Cultuurgewassen in Indonesie.

Kanamitzu K, Frank JH. 1987. Paederus, sensu lato (Coleoptera: Staphylinidae: Natural hisory and medical importance. Journal of Medical Entomology 24:155-191. doi: http://dx.doi. org/10.1093/jmedent/24.2.155.

Kartohardjono A. 1992. Preferensi predator Paederus sp. terhadap beberapa jenis wereng pada tanaman padi. Seminar Hasil Penelitian Tanaman Pangan. Balittan Bogor.

Kim S, Park, JH, Lee JH, Yang JM, Lee ES, Kim JK, Kim WS. 2007. A case of Paederus dermatitis. Annals of Dermatology 19:88-90. doi: http:// dx.doi.org/10.5021/ad.2007.19.2.88.

Kim TK, Cho YB, Ahn KJ. 2011. Two littoral species of the Genus Medon (Coleoptera: Staphylinidae: Paederinae) new to Korea. Korean Journal of Systematic Zoology. 27:69-73. doi: http://dx.doi. org/10.5635/KJSZ.2011.27.1.069.

Krebs CJ. 1999. Ecological Methodology, $2^{\text {nd }}$ ed. California: Addison-Wesley Longman, Inc.

Lou YG, Zhang GR, Zhang WQ, Hu Y, Zhang J. 2013. Biological control of rice insect pests in China. Biological Control 67:8-20. doi: http:// dx.doi.org/10.1016/j.biocontrol.2013.06.011.

Magurran AE. 1987. Ecological Diversity and Its Measurement. London: Chapman and Hill.
Newton AF, Thayer MK, Ashe JS, Chandler DS. 2000. Family 22. Staphylinidae Latreille, 1802. In: Arnett RH Jr, Thomas MC (Eds.). American Beetles, Volume 1, Archostemata, Myxophaga, Adephaga, Polyphaga: Staphyliniformia. pp. 272-418. Boca Raton: CRC Press LLC.

Putzh V. 2006. On some Stenus species from latin America (Coleoptera: Staphylinidae). Dugesiana $13: 1-21$

Ratti JT, Garton EO. 1996. Research and experimental design. In: Bookhout TA (Ed.) Research and Management Technique for Wildlife and Habitat. pp. 1-23. Bethesda: The Wildife Society.

Rozas V, Prieto JAF. 2000. Competition, mortality, and development of spatial patterns in two cantabrian populations of Fagus sylvatica L. (Fagaceae). Anales del Jardi'n Botanico de Madrid 58:117-131. doi: http://dx.doi. org/10.3989/ajbm.2000.v58.i1.144.

Riyanto, Herlinda S, Irsan C, Umayah A. 2011. Kelimpahan dan keanekaragaman spesies serangga predator dan parasitoid Aphis gossypii di Sumatera Selatan. Jurnal HPT Tropika. 11:57-68.

Sagar R, Raghubanshi AS, Singh JS. 2003. Tree species composition, dispersion and diversity along a disturbance gradient in a dry tropical forest region of India. Forest Ecology and Management 186:61-71. doi: http://dx.doi.org/10.1016/ s0378-1127(03)00235-4.

Sapkota IP, Tigabu M, Oden P. 2009. Species diversity and regeneration of old growth seasonally dry Shorea robusta forests following gap formation. The Journal of Forest Research 20:7-14. doi; http://dx.doi.org/10.1007/s11676-009-0002-6.

Sudarjat, Utomo A, Dono D. 2009. Biologi dan kemampuan memangsa Paederus fuscipes Curtis (Coleoptera: Staphylinidae) terhadap Bemisia tabaci Gennadius (Homoptera: Aleyrodidae). Jurnal Agrikultur 2:204-209.

Widya WA. 2005. Kelimpahan Kumbang Jelajah Paederus fuscipes Curtis (Coleoptera: Staphylinidae) pada Empat Ekosistem Pertanaman di Kecamatan Ciranjang, Cianjur. Skripsi. Bogor: Institut Pertanian Bogor.

Winasa IW, Hindayana D, Santoso S. 2007. Pelepasan dan pemangsaan kumbang jelajah Paederus fuscipes (Coleoptera: Staphylinidae) terhadap telur dan larva Helicoverpa armigera (Lepidoptera: Noctuidae) pada pertanaman kedelai. Jurnal Ilmu Pertanian Indonesia 12:147-153. 